\title{
8. Romanska språk som akademisk disciplin
}

\author{
Fanny Forsberg Lundell \& Lars-Göran Sundell
}

De romanska språken är latinets dotterspråk och de har en lexikal, fonologisk och grammatisk liksom en kulturell gemenskap, men samtidigt sin egen särprägel. När de moderna språken under 1800-talet blev riktiga discipliner vid de svenska universiteten sammanfördes de i språkgrupper som just romanska språk. Åtskilliga forskare genomförde då dels komparativa romanska studier, dels enskilda studier i flera av de romanska språken, företrädesvis franska, spanska, italienska och provensalska. Båda dessa forskningstraditioner har med tiden försvagats och tendensen har gått mot studier i enbart ett av de romanska språken.

Det är därför intressant att belysa vad som har hänt och händer inom romanistiken ur ett modernt forsknings- och undervisningsperspektiv. På senare tid har ämnesområdet fått en förnyad och delvis förändrad aktualitet liksom förhållandet mellan språk och litteratur. I de fyra följande reflekterande bidragen vill vi söka belysa utvecklingen av de romanska språken som studieobjekt och undervisningsämnen vid våra lärosäten.

\section{1 Är disciplinen romanska språk en enhet idag och i så fall på vilket sätt?}

Fanny Forsberg Lundell

Sedan 2013 är romanska språk en tydligare enhet vid Stockholms universitet än vad det varit på många år. Av administrativa skäl skedde då en sammanslagning av Institutionen för franska, italienska och klassiska språk och Institutionen för spanska, portugisiska och latinamerikastudier. En stor romansk enhet har alltså bildats, som även har med det gamla moderspråket latin och en samhällsvetenskaplig vinkel i och med närvaron av Latinamerikainstitutet. Denna sammanslagning, som alltså i förstone hade administrativa orsaker, har trots allt påverkat ämnesidentiteten och sammanhållningen. Det man dock bör fundera över är om och i så fall på vilka plan det kan uppfattas som mer av en enhet idag eller inte. Man kan här göra en första grov tudelning i ett forskningsperspektiv och i ett utbildningsperspektiv. 
När det gäller forskningsperspektivet finns flera exempel på forskningsprojekt som behandlar flera romanska språk. Man får emellertid skilja på projekt som behandlar flera romanska språk och projekt som anlägger ett komparativt romanskt perspektiv. Mig veterligen sysslar få forskningsprojekt idag med klassisk komparativ romanistik, men däremot har vi på senare år sett projekt där forskare från flera romanska språk ingått. Ett av dem är Avancerad andraspråksanvändning, (http://www.rj.se/globalassets/skriftserie/ rj_skriftserie_andraspraksanv.pdf), ett fakultetsövergripande program på Stockholms universitet, finansierat av Riksbankens jubileumsfond. I detta program, som intresserade sig för begränsningar och möjligheter avseende vuxnas andraspråksinlärning, ingick forskare från de romanska språken franska, italienska och spanska. Flera studier i projektet behandlar flera romanska språk på samma gång, utan att anlägga ett verkligt komparativt perspektiv. Bland dessa finner vi ordförrådsstudier av Bardel, Gudmundson \& Lindqvist (t.ex. Bardel \& Lindqvist 2011; Bardel, Gudmundson \& Lindqvist 2012) i franska och italienska och studier rörande idiomatik i franska och spanska av Forsberg Lundell \& Fant (Forsberg \& Fant 2010; Erman, Denke, Fant \& Forsberg Lundell 2014). I dessa studier fokuseras inte ett specifikt romanskt språk så mycket, utan intrycket man får är att de romanska språkens likhet används som en resurs för att kunna undersöka ett större material och därför uppnå större generaliserbarhet av resultaten. Det finns uppenbarligen fler poänger med att inkludera flera romanska språk i forskningen, förutom det komparativa. Det rör sig således om två ganska skilda syften: ett som strävar efter att belysa skillnader mellan de romanska språken och ett som syftar till att istället hitta likheter. I Erman et al. (2014) inkluderas även engelska och där ser man tydligt att kontrasten inte står att finna mellan de romanska språken, men mellan de romanska språken å sin sida och engelskan å andra sidan. Måhända finner man i dagsläget en gemenskap i de romanska språken just i förhållande till engelskan? Inte minst när det gäller läget för romanska språk i utbildning inom skolan och på högskolan.

Ett annat exempel på ett projekt på Stockholms universitet som inbegriper flera romanska språk är ROMPOL. ROMPOL inkluderar främst spanska och franska och undersöker politisk diskurs i de romanskspråkiga länderna. Projektet har arrangerat ett flertal välbesökta konferenser vid Stockholms 
universitet. Även inom detta projekt är syftet inte så mycket komparativt, med avseende på att hitta skillnader, utan snarare ett forum för att samlas kring gemensamma frågeställningar inom diskursanalys med inriktning mot romanska språk.

Det förefaller alltså som den aktuella forskning, som behandlar flera romanska språk, har som främsta mål att samla forskare med liknande intressen och liknande studieobjekt, vilket man lätt hittar då man sysslar med närbesläktade språk. Syftet att jämföra språken sinsemellan framstår som något sekundärt.

En liknande tendens går att utröna inom utbildningen. Det faktum att vi har färre studenter överlag inom romanska språk, i synnerhet på avancerad nivå, gör det nödvändigt för oss att samarbeta mer, vilket stärker den romanska identiteten. Det skulle möjligtvis kunna upplevas som en positiv konsekvens av en i övrigt negativ utveckling. Vi skapar kurser som är gemensamma för alla de romanska språken och har en kortare gemensam del på engelska och sedan specialiseringar på de olika romanska språken. Noteras bör alltså att inget av de romanska språken (än så länge i alla fall) kan fungera som lingua franca mellan studenter i olika romanska språk, utan det blir då engelskan, som får fylla den funktionen. En förhoppning är dock att dessa kurser, där man träffar studenter från flera romanska språk, ska kunna väcka intresset för att lära sig ett annat romanskt språk också. Rent konkret handlar de här kurserna alltså inte heller om att studenter får komparativa färdigheter i romanska språk, utan att man samlar studenter kring ämnen som är relevanta för alla romanska språk. Jag har själv erfarenhet av att undervisa på kursen ”Andraspråksinlärning: Romanska språk”. Ytterligare kurser på Avancerad nivå är exempelvis: "Förmedling av romansk litteratur i en globaliserad värld", "Språkkontakt, flerspråkighet och minoriteter i den romanska världen", ”De romanska språkens utveckling från latin” och "Uppkomsten av nationella litteraturer i romanska språk".

Slutligen skulle man kunna spekulera ifall gemensamma kurser för studenter i romanska språk kan vara ett sätt att stärka studenttillströmningen till våra ämnen. Vi har en förhoppning om att studierna i t.ex. franska, ska leda till nyfikenhet på studier i t.ex. italienska och att vi på så sätt kan behålla studenterna ett tag till på institutionen. Ytterligare ett sätt att uppmuntra detta vore att ha en kortversion av "Att förstå romanska språk"-kursen inom 
kanske termin 1 eller snarare $2 \mathrm{i}$ det valda romanska språket. Vi lärare borde också gå en sådan kurs för att skapa större sammanhållning och skapa ännu bättre förutsättningar för samarbeten över språkgränserna.

\subsection{Konsekvenser av FoRom och}

\section{andra utbildningsinitiativ med "flerromansk inriktning" Fanny Forsberg Lundell}

Forskarskolan i romanska språk (FoRom) var ett samarbete mellan Stockholms universitet, Växjö universitet (idag Linnéuniversitetet), Mälardalens högskola, Karlstads universitet och Högskolan i Gävle. Verksamheten pågick mellan 2001 och 2014. 28 doktorander och 11 postdok-anställningar rymdes inom forskarskolan. Vi som hade förmånen att doktorera inom FoRom fick ta del av flera gynnsamma aktiviteter. I början av vår utbildning fick vi gå en 7,5 hp kurs i "Att förstå romanska språk", vilket gav oss nycklar till att få en passiv förståelse av de andra romanska språken, genom den välbeprövade metoden EuRom4 (Blanche-Benveniste et al. 1997). Den främsta anledningen att tillägna sig denna kompetens, var att vi inom forskarskolan skulle kunna läsa varandras texter och vara opponenter på forskarskolans gemensamma seminarier. Inom FoRom odlades ingen komparativ romansk språkforskning, men däremot odlades en gemenskap och den passiva förståelsen för de andra romanska språken ökade. Inom den gemensamma kursen "De romanska språkens utveckling", 7,5 hp, anlades emellertid ett mer komparativt perspektiv. Inom denna kurs blev vi medvetna om grundläggande skillnader i hur de romanska språken utvecklats och deras särdrag men det var inget som senare fortplantade sig inom forskningen. Utöver kursen om de romanska språkens utveckling skulle jag vilja påstå att FoRom framför allt förstärkte det "gemensamma" mellan språken och att språken faktiskt ibland kom lite i bakgrunden. Det blev tydligare att vi orienterade oss inom grupper som "kognitiv lingvistik", "andraspråksinlärning", "kontrastiv lingvistik" och "språkhistoria" och att det särspråkliga suddades ut i någon mån.

För att summera kan vi konstatera att ett angreppssätt till det gemensamma romanska som växte fram inom FoRom, har fortplantat sig inom dagens forskning och utbildning inom romanska språk. Det romanska blir 
en gemensam plattform, för att utforska frågor som är relevanta för flera romanska språk. Frågan är ju om vi i framtiden kommer att se forskning och utbildning som ägnar sig åt mer komparativa perspektiv. I detta sammanhang skulle man även kunna skapa områdeskurser inriktade på den romanska världen, som en språklig gemenskap med vissa gemensamma, men också särskiljande kulturella drag.

\subsection{Vilket är ämnets identitet och relevans idag?}

\section{Lars-Göran Sundell}

Med vilka romanska språk bör en romanist sysselsätta sig? Bland det första seklets svenska romanister (ca 1860-1960) positionerar sig flera ideologiskt i förhållande till denna fråga. Redan Friedrich Diez (1794-1876), professor i Bonn år 1830 och ansedd som den romanska disciplinens grundläggare, anger utgångsläget för den komparativa romanistiken med sex romanska språk att ta i beaktande: italienska, rumänska, spanska, portugisiska, provensalska och franska. Med hänvisning till Diez lägger Carl Wilhelm Böttiger (1807-1878), den förste professorn i Nyeuropeisk lingvistik och modern litteratur på svensk botten i Uppsala 1858, till rätoromanskan på denna lista. Hans efterträdare Theodor Hagberg ursäktar sig i ett tidigt jämförande romanskt specimen att han tyvärr måste utelämna rätoromanskan i brist på empiriskt underlag och detta naturligtvis med anspelning på Böttigers ställningstagande. I Lund för Edvard Lidforss in katalanskan på den svenska romanska agendan liksom senare Alf Lombard definitivt introducerar rumänskan och etablerar den romanska fyrklövern italienska, franska, spanska och rumänska.

Som gemensam nämnare gäller att de ovan nämnda befattningshavarna liksom deras samtida alla var romanister i den meningen att de sysselsatte sig med flera romanska språk. Belysande är ett citat från Edvard Lidforss' efterträdare i Lund Fredrik Wulff, när han i Paris av Gaston Paris "lärde sig att klassificera handskrifter” och det gällde då franska sådana:

De övriga romanska språken sysslade jag naturligtvis också flitigt med, särskilt under mina resor i Spanjen, Portugal och Italien. (Wulff 1929: 345) 
Det är viktigt att hålla i åtanke att under den svenska romanistikens första sekel gällde för professorstjänsterna, och andra fasta forskningstjänster fanns inte, tjänstebeteckningen 'Romanska språk'. Skulle man således kunna komma ifråga för en tjänst med denna ämnesbeskrivning var det nödvändigt att speciminera i flera av de romanska språken. Det fanns däremot inte något uttalat krav på komparativ romanistik, utan man kunde lika gärna ta sig an olika problem inom respektive språk, vilket snarast var det vanliga om man ser till de publikationer som utgavs i form av monografier och artiklar.

\section{crs}

För att övergå till dagens situation kan vi då fråga oss: Vad har vi? Vad vill vi ha? Och vem bestämmer i så fall vad vi ska ha?

Det är lätt att konstatera att tjänsternas inriktning med logisk konsekvens är avgörande för hur man väljer att speciminera, om det nu är en akademisk karriär som hägrar. Den krassa verkligheten styr, även om det i botten ligger en ideologisk färdriktning, frågan är bara vem som bestämmer. Institutionellt existerar idag inte i Sverige ämnet romanska språk i dess äldre utformning, vilket naturligtvis inte hindrar enskilda forskare från att ägna sig åt flera romanska språk eller åt komparativ romanistik, när de väl etablerat sig inom någon befintlig disciplin, det må gälla tjänst i ett enskilt romanskt språk eller i romanska språk, men i det senare fallet i våra dagar alltid med tillägget särskilt franska, spanska eller italienska.

1960-talets omstrukturering av den romanska disciplinen innebar att franska, spanska och italienska lyftes fram som egna ämnen inom grundutbildningen och därmed inte längre fanns under den romanska paraplyn. I samband med denna förändring inrättades tjänster som universitetslektor i de enskilda språken, även om någon äldre befattningshavare hann tillträda som universitetslektor i romanska språk. Inom forskarutbildningen behölls dock som regel de gamla övergripande romanska benämningarna liksom på flera håll institutionsbeteckningen 'Romansk institution'.

I sin installationsföreläsning gav professor Lombard en lägesbeskrivning över de romanska studiernas dåvarande situation:

I våra dagar sysslar språkforskningen i den romanska världen främst med det egna landets tungomål, och därav följer även att de samromanska 
studierna stå högre i kurs utanför än inom den romanska världen. (Lombard 1939: 556)

Man kunde kanske tycka att det borde vara upp till den s.k. professionen att bestämma färdriktningen och de enskilda ämnesinstitutionerna har naturligtvis fortfarande ett visst inflytande på den interna ämnesorganisationen, om än inte någon entydig beslutanderätt. Men i ett nationellt perspektiv ter det sig betydligt mer problematiskt, och detta inte minst med tanke på universitetens autonomi, att få till stånd en övergripande plan. Beroende i hög grad på ekonomiska faktorer finns vid lärosätena i olika omfattning främst tjänster i dagens tre 'stora' romanska språk: franska, spanska och italienska, det vill säga de ämnen vilka förutsätts kunna locka flest studenter. I mån av resurser, tradition, kompetens m.m. ges i förekommande fall därutöver undervisning i portugisiska, rumänska, katalanska, provensalska. Inget hindrar i och för sig en annorlunda ämnesindelning med samromansk inriktning, inte minst för de fåtaliga forskartjänsterna. Detta vore då i viss mån en återgång till en äldre situation, men en sådan utveckling förefaller mindre sannolik, även om den har sina förespråkare. Den långt drivna specialiseringen inom de enskilda språken motverkar också en sådan utveckling. Åtskilliga moderna 'enspråkiga romanister' - termen används emellanåt om forskare som ägnar sig åt enbart franska, i brist på en adekvat term motsvarande hispanist och italianist - har dessutom ofta i sin forskning beröringspunkter med områden som naturligt inkluderar andra icke-romanska språk snarare än ytterligare romanska språk.

Nytt är idag att behovet av en nationell språkstrategi åter aktualiseras från flera aktörer och detta i ljuset av den radikalt förändrade språkliga verkligheten i Sverige. Fokus läggs då på minoritetsspråk utifrån migrations- och integrationsperspektiv och även behovet av forskning och undervisning i svenska som andraspråk. Det är notabelt att enbart vid den språkvetenskapliga fakulteten vid Uppsala universitet bedrivs för närvarande undervisning och forskning i ett fyrtiotal språk. 


\section{4 Är det lika motiverat att fokusera romansk litteratur som språk? Lars-Göran Sundell}

När det gäller frågeställningen språk i förhållande till litteratur och deras samexistens inom de språkvetenskapliga ämnesinstitutionerna är en historisk tillbakablick belysande. Diskussionen som sådan kan spåras redan till tiden för inrättandet av ämnet Nyeuropeisk lingvistik och modern litteratur kring 1860, även om debatten sedan dess förts och idag förs under delvis andra förutsättningar.

Förhistorien är något olika i Lund och Uppsala, men något förenklat kan man konstatera att det är ämnet Estetik som uppdelas i två grenar, dels alltså Nyeuropeisk lingvistik och modern litteratur och dels Estetik samt litteratur- och konsthistoria, dvs. i praktiken med huvudinriktning mot antingen språk i det första fallet eller mot litteratur i det andra. Inom denna senare inriktning träffar vi på berömda litteraturvetare som Gustaf Ljunggren, Henrik Schück och Bernard Elis Malmström. Boskillnaden mellan de två grenarna var till en början långt ifrån kristallklar och Carl Wihelm Böttiger, den förste professorn i Uppsala i Nyeuropeisk lingvistik och modern litteratur 1858, kunde lika väl ha valt tjänsten i Estetik samt litteratur- och konsthistoria vid estetiktjänstens klyvning, men han valde alltså den språkligt inriktade tjänsten.

Den mer renodlade litteraturvetenskapen hamnar således inom ämnet Estetik med litteratur- och konsthistoria, sedermera i en första omgång omdöpt till litteraturhistoria med poetik. Två belysande romanska exempel från Uppsala utgörs av Carl David af Wirsén, Svenska Akademiens berömde ständige sekreterare, som 1868 disputerade på avhandlingen Studier rörande reformerna inom den franska vitterheten under sextonde och nittonde seklen och Oscar Levertin, som disputerade 1888 på avhandlingen Studier öfver fars och farsörer i Frankrike mellan renaissancen och Molière. Levertin studerade bland annat för Böttigers efterträdare Theodor Hagberg och hade som fakultetsopponent Carl Wahlund, en av det romanska seminariets mest prominenta medlemmar. Både af Wirsén och Levertin disputerade inom ämnet Estetik med litteratur- och konsthistoria. 
Per Adolf Geijer, Uppsalas förste professor i romanska språk 1890, varseblev tidigt problematiken och redan efter en studieresa i Tyskland 1873 meddelade han följande iakttagelse:

I Tyskland är professorn i språket äfven ansvarig för undervisningen i detta språks litteraturhistoria, då deremot hos oss den moderna litteraturhistorien blifvit öfverflyttad till den estetiska professuren. Att skäl finnas, som tala för denna senare anordning, vill jag ej bestrida, men tror dock, att det skulle hos de studerande höja intresset för det moderna språkstudiet, om med detsamma en litteraturhistorisk kurs vore nödvändigt förenad och inginge som fordran i examen. Studiet blefve derigenom fullständigare och följaktligen mera tillfredsställande. Inom de klassiska språken är detta hos oss ännu förhållandet, och jag betviflar, att professorerna i dessa språk skulle gå in på att så fullständigt lemna ifrån sig den grekiska och latinska litteraturhistorien, att de af sina alumner ej hade rättighet fodra ens den allra mest summariska kännedom deri. (Geijer 1876: 8)

$\mathrm{Nu}$ är emellertid paradoxen den att inom den romanska disciplinen inträffade den skarpa bodelningen mellan språk och litteratur först under Per Adolf Geijers egen professorstid. Carl Wilhelm Böttiger och Theodor Hagberg lät sig inte insnärjas i en snäv ämnesbeskrivning utan upprätthöll såväl litterära som språkvetenskapliga traditioner inom sitt ämne i Uppsala, som för deras vidkommande ju fortfarande var Nyeuropeisk lingvistik och modern litteratur. Detsamma gällde för Edvard Lidforss under hans ämbetsperiod i Lund.

\section{cos}

I dagens situation när tjänster med litterär inriktning naturligt kommit att ingå i läraruppsättningen åtminstone vid de större romanska ämnesinstitutionerna, är det erfarenhetsmässigt lätt att konstatera att samexistensen mellan språk och litteratur inte alltid är helt problemfri. Till syvende och sist gäller ju att alla 'intressen' måste samsas om den gemensamma ekonomiska resursen, vilket emellanåt medför interna motsättningar, visserligen ofta välmotiverade utifrån specifika ämnesperspektiv, men inte nödvändigtvis alltigenom positiva för den institutionella enheten.

Mitt eget credo, som jag med växlande framgång torgförde när jag var prefekt under tio år fram till 2001 vid dåvarande Romanska institutionen i Uppsala, och som jag fortfarande skulle vilja hävda, är att en akademisk 
lärare i normalfallet inom sitt språkområde borde kunna undervisa på alla inom grundutbildningen befintliga moment, dvs. huvudsakligen språk, litteratur och realia. Forskningsanknytningen hos respektive lärare kan då av naturliga skäl inte alltid garanteras för varje enskilt moment utan en idealsituation kommer att ställas mot en allt som oftast krass ekonomisk verklighet, vilken medger ett begränsat antal tjänster. Hur som helst rör det sig om en fortgående debatt som i praktiken med olika förtecken har pågått alltsedan de moderna språken inrättades på akademisk nivå vid de svenska universiteten kring 1860.

\section{Bibliografi}

Bardel, Camilla, Gudmundson, Anna \& Lindqvist, Christina, 2012: Aspects of lexical sophistication in advanced learners' oral production: vocabulary acquisition and use in L2 French and Italian. I: Abrahamsson, Niclas \& Hyltenstam, Kenneth (red.), High-level L2 Acquisition, Learning and Use. Thematic issue of Studies in Second Language Acquisition, 34/2. 269-290.

Bardel, Camilla \& Lindqvist, Christina, 2011: Developing a lexical profile for spoken French and Italian L2. The role of frequency, cognates and thematic vocabulary. I: Roberts, Lea, Pallotti, Gabriele \& Bettoni, Camilla. EUROSLA Yearbook, vol. 11. Amsterdam: John Benjamins. 75-93.

Blanche-Benveniste, Claire et al. 1997: EuRom4. Milano: Editrice La Nuova Italia.

Erman, Britt, Denke, Annika, Fant, Lars \& Forsberg Lundell, Fanny, 2014: Nativelike expression in long-residency L2 users: A study of multiword structures in the speech of L2 English, French and Spanish. International Journal of Applied Linguistics (IJAL), 24/1. doi: 10.1111/ijal.12061

Forsberg, Fanny \& Fant, Lars, 2010: Idiomatically speaking: The effects of task variation and target language on the use of formulaic sequences in high-level use of French and Spanish. I: Wood, David (red.), Perspectives on Formulaic Language. London/New York: Continuum. 47-70.

Geijer, Per Adolf, 1876: Meddelanden om skolor och universitet i Tyskland, Italien och Frankrike. Reseberättelse. Uppsala universitets årsskrift. Upsala: E. Edquists boktryckeri.

Lombard, Alf, 1939: Romansk språkforskning. En översikt över aktuella spörsmål och arbetsuppgifter. Nordisk familjeboks månadskrönika. Häfte 8. Augusti-September 1939. 556-562.

Wulff, Fredrik, 1929: Vid åttiofem år. Hågkomster frän utvecklingsåren 1865-80, av en gammal Lundastudent och Göteborgare. Göteborg: Elanders BoktryckeriAktiebolag. 